\title{
Preface to \\ Rabindranath Tagore, The Post Office, tr. Devabrata Mukerjea (1914)
}

When this little play was performed in London a year ago by the Irish players, ${ }^{1}$ some friends of mine discovered much detailed allegory, the Headman being one principle of social life, the Curdseller or the Gaffer another; but the meaning is less intellectual, more emotional and simple. ${ }^{2}$ The deliverance sought and won by the dying child is the same deliverance which rose before his imagination, $\mathrm{Mr}$ Tagore has said, when once in the early dawn he heard, amid the noise of a crowd returning from some festival, this line out of an old village song, 'Ferryman, take me to the other shore of the river.' It may come at any moment of life, though the child discovers it in death, for it always comes at the moment when the 'I', seeking no longer for gains that cannot be 'assimilated with its spirit', is able to say, 'All my work is thine'. ${ }^{3}$ On the stage the little play shows that it is very perfectly constructed, and conveys to the right audience an emotion of gentleness and peace.

W. B. Yeats 